\title{
PERMAINAN TRADISIONAL “CUBLAK SUWENG” UNTUK MENINGKATKAN KETERAMPILAN SOSIAL ANAK SD
}

\author{
Afakhrul Masub Bakhtiar1 ${ }^{*}$, Paulina ${ }^{2 *}$ \\ 1 Universitas Muhammadiyah Gresik \\ 2 Universitas Muhammadiyah Gresik
}

\begin{abstract}
Abstrak
Permainan tradisional yang merupakan salah satu kekayaan intelektual bangsa, yang mengandung syarat akan makna kehidupan. Penelitian ini bertujuan untuk meningkatkan keterampilan sosial anak SD melalui permainan tradisional "Cublak Suweng" untuk diangkat dalam pembelajaran. Dengan diangkatnya permainan tradisional "Cublak Suweng", secara otomatis akan mengenalkan dan membudayakan budaya kearifan lokal pada siswa SD. Untuk mencapai target peningkatan keterampilan sosial anak SD melalui permainan tradisional "Cublak Suweng", peneliti melakukan penelitian tindakan kelas yang berkolaborasi dengan guru SDN 1 Lampah, Kedamean, Gresik. Penelitian tindakan kelas ini dilakukan dalam tiga siklus, masingmasing siklus meliputi tahapan perencanaan, pelaksanaan dan observasi, serta refleksi. Hasil analisis data menunjukkan bahwa aktivitas siswa pada siklus I mencapai $76,2 \%$, pada siklus II meningkat menjadi $82,6 \%$, dan pada siklus III meningkat menjadi $85,9 \%$. Begitu juga dengan hasil analisis data keterampilan sosial siswa pada siklus I yang mencapai 79\%, pada siklus II meningkat menjadi 85\%, dan pada siklus ketiga meningkat menjadi $88 \%$. Berdasarkan hasil tersebut, dapat disimpulkan bahwa melalui permainan tradisional "Cublak Suweng" keterampilan sosial siswa dapat ditingkatkan.
\end{abstract}

\author{
Keywords: \\ Keterampilan Sosial, \\ Permainan Tradisional
}

\section{Pendahuluan}

Anak adalah manusia kecil yang memiliki potensi yang masih harus dikembangkan. Anak memiliki karakteristik yang khas dan tidak sama dengan orang dewasa, mereka selalu aktif, dinamis, antusias, dan selalu ingin tahu terhadap apa yang dilihat, didengar, dirasakan, mereka seolah-olah tak pernah bereksplorasi dan belajar (Nopilayanti, 2016). Anak secara kodrati merupakan makhluk sosial. Anak-anak secara naluriah adalah anak yang aktif bergerak, dengan bergerak itulah anak meperoleh pengalaman melalui tempat-tempat bermain, di sekolah dan di lingkungan masyarakatnya yang lebih luas (Hasibuan, 2010). Namun dalam perkembangannya identitas "sosial" pada era sekarang mulai memudar. Hal ini terlihat dari pola hidup anak, dimana ketergantungan pada teknologi sangatlah tinggi. Seperti yang diungkap oleh Achroni (2012), mengatakan bahwa pola hidup anak di era sekarang ini sangatlah berbeda. Pola hidup masa kini selalu disibukkan dengan kegiatannya masing-masing, seperti bermain play station, game online, blackberry atau internet menjadi suatu kebiasaan sehari-hari yang apabila tidak dibatasi dalam penggunaanya maka dapat mempengaruhi kehidupan sosial anak. Pada perkembangan fasilitas dan akses yang serba modern, tidak hanya orang dewasa yang dapat menikmati kemudahannya akan tetapi kalangan anak-anak juga bisa menikmati fasilitas tersebut. Fasilitas seperti play station maupun game-game online sudah ada di berbagai daerah dan bisa diakses melalui internet maupun handphone yang kini sudah dimilki oleh siapa saja. Dampak dari tidak terkontrolnya dalam bermain game akan membuat anak kehilangan waktu untuk bersosialisasi. Hal ini dapat mengakibatkan anak menjadi terisolasi dari pergaulan dan keterampilan sosialnya menjadi tidak berkembang, serta kepekaan sosial anak pun akan menjadi rendah (Achroni, 2012). Selain karena permainan modern, rendahnya keterampilan sosial anak juga disebabkan karena kurangnya waktu bermain dengan teman-temannya. Kecenderungan orang tua yang lebih menekankan anak untuk terus belajar tanpa diimbangi dengan bermain merupakan salah satu faktor penyebab rendahnya keterampilan sosial anak. Pandangan yang keliru tentang aktivitas bermain pada anak ini membuat banyak orang tua mengabaikan hak anak untuk bermain (Achroni, 2012). 
Berdasarkan hasil observasi yang dilakukan di sekolah, menunjukkan bahwa kecenderungan anak melakukan perilaku yang kurang baik salah satunya disebabkan oleh kegemaran anak dalam melakukan permainan atau bermain game online yang terdapat dalam handphone maupun internet yang pemakaiannya berlebihan. Game tersebut menyebabkan anak terisolasi dari pergaulannya yang berimbas keterampilan sosial anak yang rendah. Pola keterampilan sosial melalui permainan modern tidak bisa mengekspresikan hubungan sosial dua arah. Oleh sebab itu pentingnya permainan tradisional diterapkan dalam model pembelajaran adalah sebagai sarana untuk melatih dan meningkatkan keterampilan sosial anakPermainan tradisional menitikberatkan pada hubungan dua arah atau lebih, kerjasama, empati dan tanggung jawab. Aktivitas bermain anak-anak merupakan suatu proses pendidikan dan pengajaran karena mainan mencerminkan sarana yang efektif dan sukses untuk mengaktualisasikan diri (Qoyyimah, 2016). Bermain memberikan anak untuk mendapatkan berbagai pengalaman belajar, seperti mengalah, dapat memahami teman lain, belajar bersikap demokratis, dan belajar bersosialisasi. Sifat-sifat baik dapat diperoleh dari permainan yang bersifat tradisional karena munculnya interaksi anak dengan teman bermainnya. Munculnya interaksi sosial anak melalui permainan tradisional dapat memberikan bekal bagi anak untuk kehidupannya kelak. Permainan tradisional juga mengandung nilai-nilai budaya tertentu serta mempunyai fungsi melatih pemainnya melakukan hal-hal penting yang nantinya sangat bermanfaat bagi kehidupan mereka di tengah masyarakat, seperti melatih cakap hitung-menghitung, melatih kecakapan berpikir, melatih keberanian, melatih bersikap jujur, sportif, dan sebagainya (Tashadi, 1993). Permainan tradisional biasanya dimainkan anak-anak setelah pulang sekolah dan dapat juga diterapkan di sekolah dasar untuk menunjang perkembangan anak. Permainan ini dapat berjalan dengan baik apabila guru memandang permainan sebagai suatu media pembelajaran yang dapat memberikan kontribusi yang berharga pada perkembangan sosial anak. Fungsi permainan tradisional secara umum adalah sebagai penghibur atau kesenangan dan sebagai pelepas lelah (Arikunto, 2006). Selain itu melalui permainan olahraga tradisional selain diperkenalkan pada budaya daerah, siswa juga diajak untuk bergerak dan belajar melalui gerak (Wijaya, 2009). Indonesia memiliki banyak permainan tradisional dari berbagai daerah yang kini sudah banyak ditinggalkan oleh anak-anak. Banyak sekali manfaat yang diperoleh dari permainan tradisional selain medianya yang ramah lingkungan. Permainan tradisional bias melatih kecerdasan anak serta sosialisasi yang baik, dapat meningkatkan percaya diri pada anak, karena permainannya sebagian besar berkelompok sehingga memerlukan kerjasama dan interaksi. Nilai-nilai positif yang terdapat pada permainan tradisional bisa diterapkan di sekolah untuk membentuk karakter anak usia SD dan tentunya dapat melestarikan permainan tradisional sebagai warisan budaya yang tidak ternilai harganya.

Permainan "Cublak Suweng" salah satu permainan tradisional yang di dalamnya mengadung syarat akan makna kehidupan. Cublak Suweng dapat meningkatkan keterampilan sosial anak karena mengandung nilai-nilai pendidikan, meliputi: kejujuran, sportif, tanggung jawab, keberanian, kepedulian, kepercayaan, kerja sama dan kerelaan. Cublak Suweng dimainkan secara berkelompok. Sambil terus bernyanyi, seorang dari mereka memberikan potongan genteng kepada teman di sebelahnya yang kemudian diteruskan kepada temannya yang lain. Potongan genteng terus berputar mengikuti tembang, sampai semua anak kebagian. Sementara itu seorang anak yang lain tertelungkup di tengah lingkaran. Ketika tembang selesai, semuanya langsung terdiam. Anak di tengah lingkaran tadi bangun. Ia harus harus menebak dengan tepat di tangan siapa potongan genteng tadi berhenti. Cublak Suweng akan mengajarkan anak untuk berinteraksi sosial. Berangkat dari kenyataan di atas, maka pilihan peneliti adalah menggunakan permainan tradisional Cublak Suweng sebagai langkah nyata untuk meningkatkan keterampilan sosial anak. Peneliti terdorong untuk mengungkapkan peningkatan keterampilan sosial melalui permainan tradisional Cublak Suweng pada anak kelas IV SDN 1 Lampah Kecamatan Kedamean Kabupaten Gresik. Berdasarkan hasil observasi peneliti, SDN 1 Lampah dipilih peneliti karena tergolong sekolah yang masuk wilayah desa termiskin Kabupaten Gresik. Dengan masyarakatnya yang tergolong mampu atau sukses, enggan untuk hidup di Desa Lampah. Sehingga masyarakatnya benarbenar solidaritas dalam membangun desa dirasa kurang. Tentu peneliti tidak bisa mengubah pola pikir masyarakat secara luas. Namun peneliti mempunyai optimisme melalui pendidikan. Pola pikir akan terbentuk, keterampilan sosial anak akan terlatih, terasah, dan terus berkembang. Dengan permainan tradisional Cublak Suweng ini dirasa sangat realistis, karena permainan sangat akrab dengan anak di desa. Secara umum penelitian tentang permainan tradisional "Cublak Suweng" ini dirasa sangat penting karena permainan-permainan tradisional Indonesia sudah banyak ditinggalkangenerasi muda. 


\section{Metode Penelitian}

Penelitian ini menggunakan tahapan siklus dalam Penelitian Tindakan Kelas (PTK). Penelitian ini dilaksanakan di SDN 1 Lampah, Kecamatan Kedamean, Kabupaten Gresik, Propinsi Jawa Timur.Penelitian ini dirancang dengan tahapan siklus PTK. Setiap siklus mempunyai empat tahapan, yaitu (1) perencanaan; (2) pelaksanaan dan pengamatan; (3) refleksi. Teknik pengumpulan data didapat dari: (1) observasi; (2) angket; (3) wawancara. Observasi digunakan untuk mengamati dan menganalisis dalam pelaksanaan permainan tradisional Cublak Suweng. Angket diberikan kepada siswa agar dapat mengetahui respon, pandangan serta sikap siswa mengenai pembelajaran dengan permainan tradisional Cublak Suweng. Wawancara digunakan peneliti untuk mendapat data dari unsur guru. Data yang diperoleh dalam penelitian ini adalah analisis kualitatif dan kuantitatif, yaitu merangkum hasil pengamatan dengan menggunakan kode- kode, gambar, diagram, angka dan tabel. Analisis data lebih difokuskan selama proses di lapangan bersamaan dengan pengumpulan data. Dalam penelitian ini terdapat empat jenis data yang diperoleh yaitu data hasil observasi, data hasil angket, dan data hasil wawancara. Data dalam penelitian ini, diperoleh dengan menggunakan instrumen observasi dan wawancara. Data dianalisis dengan deskriptif kualitatif. Sedangkan data yang diperoleh dengan angket dianalisis secara kuantitatif.

\section{Hasil Dan Pembahasan}

\section{Hasil}

1. Deskripsi Siklus I

Siklus I dilaksanakan pada 20 April 2017. Kegiatan yang dilakukan pada tahap pelaksanaan ini berupa penerapan model pembelajaran dengan permainan Cublak Suweng yang telah dirancang dalam RPP. Adapun kegiatan pembelajaran yang dilakukan terdiri dari beberapa tahap. Pada tahap pendahuluan, beberapa aktivitas yang dilakukan guru dan siswa; siswa menyimak dan merespon motivasi guru terkait tentang permainan tradisional. Siswa menyimak tujuan pembelajaran yang disampaikan guru dengan rasa ingin tahu dan peduli. Siswa menyimak video tentang permainan tradisional. Siswa merespon pertanyaan guru terkait video yang ditayangkan. Pada tahap berikutnya dimulai dari: siswa membentuk kelompok kecil (lima-enam siswa tiap kelompok). Setiap kelompok mempelajari cara bermain cublak suweng. Kemudian mempraktikan permainan tradisional Cublak Suweng. Melakukan diskusi dan guru memberi penguatan terkait hasil diskusi. Pada tahap akhir, yakni siswa beserta guru menyimpulkan materi yang telah dipelajari tentang nilai-nilai sosial. Guru mengevaluasi hasil observasi penilaian sikap (keterampilan sosial). Guru memberi penguatan terhadap hasil observasi peningkatan keterampilan sosial dengan permainan tradisional Cublak Suweng. Guru memberi motivasi kepada siswa untuk melestarikan permainan tradisional. Kegiatan pembelajaran ditutup dengan doa dan salam. Pengamatan, kegiatan pengamatan dilaksanakan ketika kegiatan pembelajaran berlangsung. Peneliti bekerja sama dengan dua observer untuk melakukan pengamatan aktivitas belajar siswa selama kegiatan pembelajaran berlangsung. Berdasarkan data hasil observasi aktivitas siswa dengan permainan sublak suweng pada siklus I memperoleh persentase 75,8\%. Berdasarkan data, sebanyak 15 siswa atau 50\% siswa dengan tingkat Keterampilan Sosial yang sangat baik, sebanyak 13 siswa atau 43\% siswa dengan tingkat Keterampilan Sosial baik, dan sebanyak 2 siswa atau 7\% siswa dengan tingkat keterampilan sosial cukup. Presentasi klasikal tingkat keterampilan sosial siswa mencapai $79 \%$ dengan kategori baik. Refleksi, berdasarkan hasil pengamatan, guru bersama observer melakukan refleksi sebagai evaluasi terhadap kegiatan pembelajaran yang telah dilakukan pada siklus I. Hal ini akan dijadikan acuan dalam siklus II.

2. Deskripsi Siklus II

Kegiatan yang dilakukan pada tahap ini sama dengan yang dilaksanakan pada tindakan siklus 1 yaitu menerapkan pembelajaran cublak suweng. Kegiatan yang dilakukan pada tahap pelaksanaan ini berupa penerapan model pembelajaran dengan permainan Cublak Suweng yang telah dirancang dalam RPP. Adapun kegiatan pembelajaran yang dilakukan terdiri dari beberapa tahap. Pada tahap pendahuluan, beberapa aktivitas yang dilakukan guru dan siswa; siswa menyimak dan merespon motivasi guru terkait tentang permainan tradisional. Siswa menyimak tujuan pembelajaran yang disampaikan guru dengan rasa ingin tahu dan peduli. Siswa menyimak video tentang permainan tradisional. Siswa merespon pertanyaan guru terkait video yang ditayangkan. Pada tahap berikutnya dimulai dari: siswa membentuk kelompok kecil (lima-enam siswa tiap kelompok). Setiap kelompok mempelajari cara bermain cublak suweng. Kemudian mempraktikan permainan tradisional Cublak Suweng. Melakukan diskusi dan guru memberi penguatan terkait hasil diskusi. Pada tahap akhir, yakni 
siswa beserta guru menyimpulkan materi yang telah dipelajari tentang nilai-nilai sosial. Guru mengevaluasi hasil observasi penilaian sikap (keterampilan sosial). Guru memberi penguatan terhadap hasil observasi peningkatan keterampilan sosial dengan permainan tradisional Cublak Suweng. Guru memberi motivasi kepada siswa untuk melestarikan permainan tradisional. Kegiatan pembelajaran ditutup dengan doa dan salam. Pengamatan, kegiatan pengamatan dilaksanakan ketika kegiatan pembelajaran berlangsung. Peneliti bekerja sama dengan dua observer untuk melakukan pengamatan aktivitas belajar siswa selama kegiatan pembelajaran berlangsung. Data hasil pengamatan aktivitas belajar siswa dapat dilihat pada tabel berikut. Berdasarkan data sebanyak 21 siswa atau $70 \%$ siswa dengan tingkat keterampilan sosial yang sangat baik dan sebanyak 9 siswa atau 30\% siswa dengan tingkat keterampilan sosial baik. Presentasi klasikal tingkat keterampilan sosial siswa mencapai $85 \%$ dengan kategori sangat baik.

\section{Deskripsi Siklus III}

Kegiatan yang dilakukan pada tahap ini sama dengan yang dilaksanakan pada tindakan siklus 1 dan 2 yaitu menerapkan pembelajaran cublak suweng. Kegiatan yang dilakukan pada tahap pelaksanaan ini berupa penerapan model pembelajaran dengan permainan Cublak Suweng yang telah dirancang dalam RPP. Adapun kegiatan pembelajaran yang dilakukan terdiri dari beberapa tahap. Pada tahap pendahuluan, beberapa aktivitas yang dilakukan guru dan siswa; siswa menyimak dan merespon motivasi guru terkait tentang permainan tradisional. Siswa menyimak tujuan pembelajaran yang disampaikan guru dengan rasa ingin tahu dan peduli. Siswa menyimak video tentang permainan tradisional. Siswa merespon pertanyaan guru terkait video yang ditayangkan. Pada tahap berikutnya dimulai dari: siswa membentuk kelompok kecil (lima-enam siswa tiap kelompok). Setiap kelompok mempelajari cara bermain cublak suweng. Kemudian mempraktikan permainan tradisional Cublak Suweng. Melakukan diskusi dan guru memberi penguatan terkait hasil diskusi. Pada tahap akhir, yakni siswa beserta guru menyimpulkan materi yang telah dipelajari tentang nilai-nilai sosial. Guru mengevaluasi hasil observasi penilaian sikap (keterampilan sosial). Guru memberi penguatan terhadap hasil observasi peningkatan keterampilan sosial dengan permainan tradisional Cublak Suweng. Guru memberi motivasi kepada siswa untuk melestarikan permainan tradisional. Kegiatan pembelajaran ditutup dengan doa dan salam. Pengamatan, kegiatan pengamatan dilaksanakan ketika kegiatan pembelajaran berlangsung. Peneliti bekerja sama dengan dua observer untuk melakukan pengamatan aktivitas belajar siswa selama kegiatan pembelajaran berlangsung.

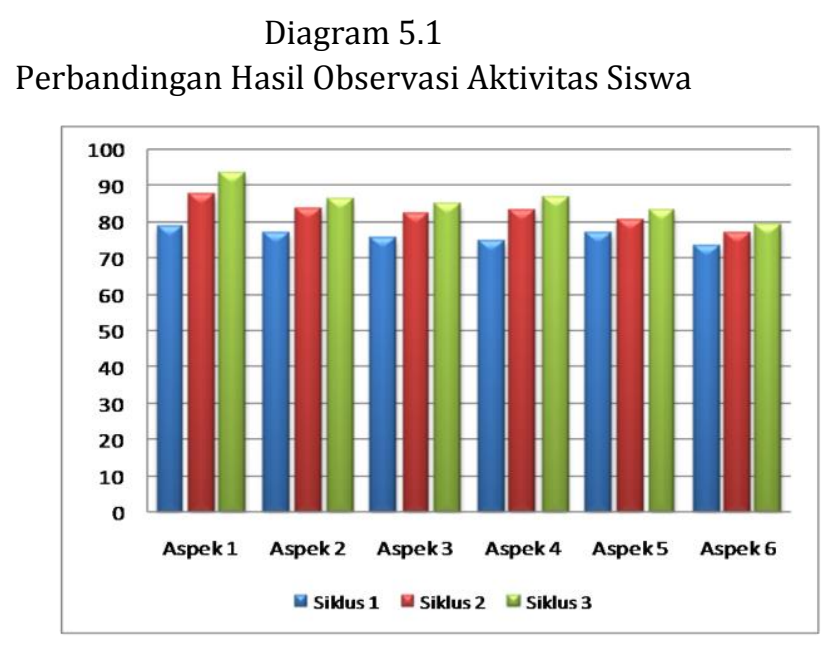

Berdasarkan data bahwa sebanyak 28 siswa atau 93\% siswa dengan tingkat keterampilan sosial yang sangat baik dan sebanyak 2 siswa atau 7\% siswa dengan tingkat keterampilan sosial baik. Presentasi klasikal tingkat Keterampilan Sosial siswa mencapai 88\% dengan kategori sangat baik. Refleksi, berdasarkan hasil pengamatan, guru bersama observer melakukan refleksi sebagai evaluasi terhadap kegiatan pembelajaran yang telah dilakukan pada siklus III. Dari evaluasi dan refleksi tersebut peneliti memperoleh kesimpulan sebagai berikut. Data aktivitas siswa dalam mengikuti kegiatan pembelajaran yang ditunjukan pada diagram 4.5 telah terlaksana dengan baik. Bahkan rata-rata aspek aktivitas siswa mengalami peningkatan dan telah melampaui indikator keberhasilan yaitu sebesar $\geq 80 \%$. Berdasarkan tabel 4.20 menunjukkan bahwa data penilaian Keterampilan Sosial siswa mengalami peningkatan dan telah mencapai indikator keberhasilan. Sebagian besar siswa telah memiliki Keterampilan Sosial. Dari 
hasil refleksi tersebut dapat diketahui bahwa siklus III sudah memenuhi indikator keberhasilan yang ditetapkan yaitu $\geq 80 \%$. Sehingga penelitian ini dinyatakan sudah cukup dilaksanakan sampai di siklus III.

Tabel 5.2

Perbandingan Penilaian Keterampilan Sosial Siswa Siklus I, II, dan III

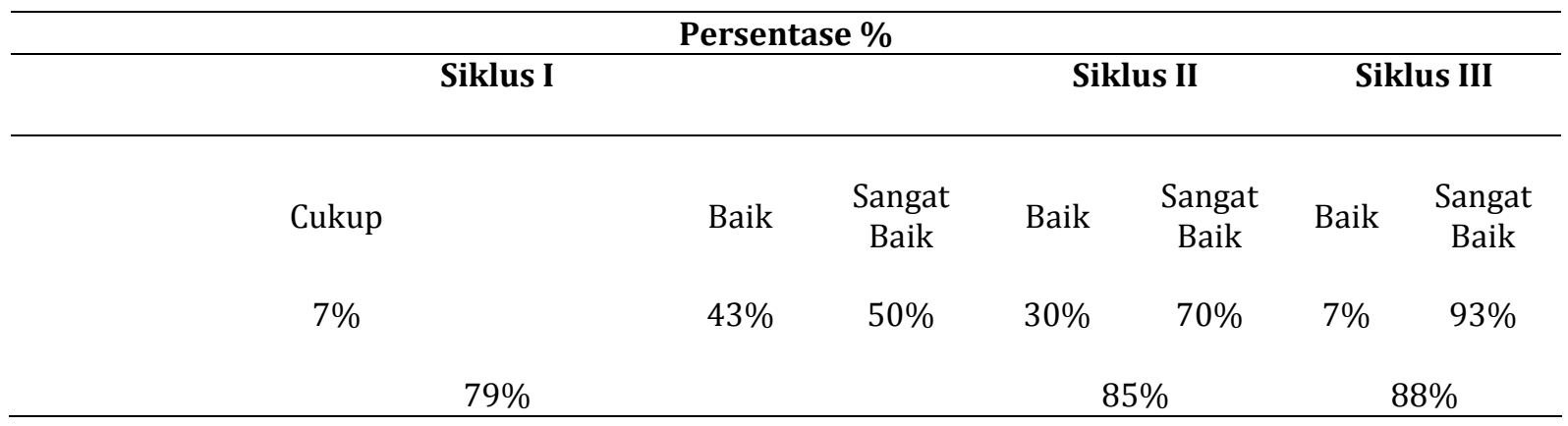

Berdasarkan data hasil observasi aktivitas siswa dalam setiap aspek mengalami peningkatan. Aspek 1 pada siklus I mencapai 79,0 \% lalu pada siklus II meningkat menjadi 87,9\%, dan pada siklus III meningkat menajdi 93,8\%. Aspek 2 pada siklus I mencapai 77,1\%, pada siklus II mencapai 83,8\%, dan pada siklus III meingkat menjadi $86,7 \%$. Aspek 3 pada siklus I mencapai $75,6 \%$, dan pada siklus II meningkat menjadi 82,5\%, dan pada siklus III meningkat menjadi 85,0\%. Aspek 4 pada siklus I mencapai 74,8\%, pada siklus II mencapai 83,3\%, dan pada siklus III meningkat menjadi 86,9\%. Aspek 5 pada siklus I mencapai 77,1\%, pada siklus II meningkat menjadi 80,8\%, dan pada siklus III meningkat menjadi 83,3\%. Aspek 6 pada siklus I mencapai 73,5\%, pada siklus II mencapai 77,1\%, dan pada siklus III mencapai 79,4\%. Data tersebut menunjukkan adanya peningkatan aktivitas siswa dalam pembelajaran dengan permainan tradisional "Cublak Suweng" dari siklus I, Siklus II, dan siklus III. Penjabaran diatas sesuai dengan apa yang dinyatakan oleh (Amir \& Nugroho, 2013; Chantaranima \& Yuenyong, 2014; Nakamura, 2010), bahwa permainan tradisional dapat meningkatkan keterampilan proses, pemecahan, menekankan cara belajar yang baik yang mencakup ranah kognitif, afektif dan psikomotorik, dan dapat mengasah keterampilan sosial. Dari data tabel 5.2 di atas, diketahui bahwa persentase tingkat keterampilan sosial siswa secara klasikal siklus I, II, dan siklus III mengalami peningkatan. Pada siklus I tingkat keterampilan sosial siswa mencapai 79\%, sedangkan pada siklus II meningkat menjadi 85\%, dan pada siklus III kembali mengalami peningkatan menjadi 88\%. Hal ini sejalan dengan pendapat (Srisawasdi \& Panjaburee, 2014), yang menyatakan bahwa Permainan Cublak Suweng, dapat meningkatkan keterampilan sosial dalam pembelajaran di sekolah.

\section{Simpulan dan Saran}

\section{Simpulan}

Meningkatkan keterampilan sosial anak dilakukan dengan pembelajaran permainan tradisional "Cublak Suweng". Rata-rata tingkatan keterampilan sosial siswa pada siklus I sebesar 79\% (baik), meningkat pada siklus II menjadi 85\% (sangat baik), dan pada siklus III kembali mengalami peningkatan menjadi 88\% (sangat baik).

\section{Saran}

Berdasarkan hasil penelitian saran yang dapat diberikan sebagai berikut. Guru sebaiknya menggunakan permainan tradisional "Cublak Suweng" untuk meningkatkan meningkatkan keterampilan sosial anak SD.

\section{Daftar Pustaka}

Achroni, Keen. (2012). Mengoptimalkan Tumbuh Kembang Anak Melalui Permainan Tradisional. Jogjakarta: Javalitera.

Amir, S., \& Nugroho, Y. (2013). Beyond the Triple Helix: Framing STS in the Developmental Context. Bulletin of Science, Technology \& Society, 33(3-4), 115-126. https://doi.org/10.1177/0270467613509603. 
Chantaranima, T., \& Yuenyong, C. (2014). The Outcomes of Teaching and Learning About Sound Based on Science Technology and Society ( STS ) Approach. Procedia - Social and Behavioral Sciences, 116, 2286-2292. https://doi.org/10.1016/j.sbspro.2014.01.561

Dharmamulya, et al. (2008). Permainan Tradisional Jawa. Yogyakarta: Penerbit kepel Press Puri arsita A-6. Dworetzky, John P. (1990). Introducion to child development dh' ed.' New York: West Publising Company.

Eliza, \& Dina Meta. (2008). Program Bimbingan Pribadi-Sosial dalam Mengembangkan Keterampilan Sosial Siswa Terisolir. Skripsi. IPB Bandung.

Elizabeth B, Hurlock. (1978). Perkembangan Anak (jilid 1, terjemahan). Inggris: McGraw-Hill.Inc

Elisabeth B. Hurlock. (1991). Child Devolopment. Tokyo: Mc Graw-Hill Kogakusha. Ltd

Fitria, Siswati, \& Prasetyo. (2009). Pengaruh Permainan Tradisional Terhadap Kompetensi Interpersonal Dengan Teman Sebaya Pada Siswa SD". Jurnal Penelitian dan Evaluasi.

Hasibuan, Rachma. 2010. Pemanfaatan Permainan Tradisional Angklik Sebagai Sumber Belajar Bidang Pengembangan Matematika Pada Anak Usia Dini. Jurnal Pendidikan dan Pengajaran Universitas

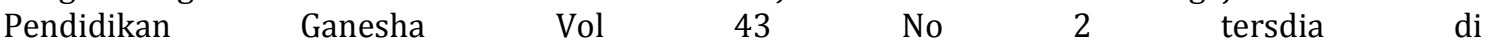
https://ejournal.undiksha.ac.id/index.php/JPP/article/view/1717/1503.

Nakamura, M. (2010). STS in Japan in light of the science caf?? movement. East Asian Science, Technology and Society, 4(1), 145-151.

Nopilayanti, Ni Kd Adi, I Km. Ngr. Wiyasa, I Gst. Agung Oka Negara. 2016. Penerapan Permainan Tradisional Engklek Untuk Mengembangkan Motorik Kasar Anak Kelompok A Tk Raisma Putra Denpasar. e-Journal Pendidikan Anak Usia Dini Universitas Pendidikan Ganesha Volume 4. No. 2.

Qoyyimah, Nurul, I Made Tegeh, Mutiara Magta. 2016. Penerapan Permainan Tradisional Untuk Meningkatkan Perkembangan Sosial Emosional Anak Kelompok A Di Ra. Baitul Muta'allim. eJournal Pendidikan Anak Usia Dini Universitas Pendidikan Ganesha Volume 4. No. 2 .

Suharsimi Arikunto. (2002). Dasar-Dasar Evaluasi Pendidikan (Edisi Revisi). Jakarta: Bumi Aksara.

Suharsimi Arikunto, et al. (2006). Permainan Tradisional di Daerah Istimewa Yogyakarta. Yogyakarta: Dinas Kebudayaan Provinsi Daerah Istimewa Yogyakarta.

Suharsimi Arikunto. (2010). Penelitian Kelas Untuk Guru, Kepala Sekolah \& Pengawas. Yogyakarta: Aditya Media

Srisawasdi, N., \& Panjaburee, P. (2014). Technology-enhanced Learning in Science, Technology, and Mathematics Education: Results on Supporting Student Learning. Procedia - Social and Behavioral Sciences, 116, 946-950. https://doi.org/10.1016/j.sbspro.2014.01.325

Tashadi (peny.). (1993). Transformasi Nilai dalm Permainan Anak. Jakarta: Dirjen Kebudayaan

Wijaya, Made Agus. 2009. Peningkatan Kebugaran Jasmani Dengan Permainan Belka Dan Permainan Tradisional Bali (Studi Eksperimen Pada Siswa Putera Kelas V Sd Lab. Undiksha). Jurnal Pendidikan dan Pengajaran Universitas Pendidikan Ganesha Vol 42, No 3 . Tersedia di https://ejournal.undiksha.ac.id/index.php/JPP/issue/view/170. 